\title{
In Search of Corporate Tax Incidence
}

\author{
December 2011
}

\author{
Kimberly A. Clausing \\ Thormund A. Miller and Walter Mintz Professor of Economics \\ Reed College \\ 3203 SE Woodstock Blvd. \\ Portland, OR 97202-8199 \\ email: clausing@reed.edu
}

\begin{abstract}
This paper reviews existing theory and empirical evidence concerning corporate tax incidence. Corporate tax incidence is difficult to establish in theory since the burden of corporate taxation will depend on at least five crucial economic parameters. Further, even if these parameters can be agreed upon, theoretical models of corporate taxation neglect at least seven important considerations. Unfortunately, existing empirical work does not provide clarification, since much of the work either relies on inappropriate tests of general equilibrium tax incidence or suffers from data or methodological limitations. This paper attempts to improve knowledge in this area by undertaking a comprehensive series of analyses of multiple data sources on labor market outcomes and corporate taxation. The analyses are informed by open-economy general equilibrium corporate tax incidence models, and they focus on OECD countries over the period 19812009. Results indicate substantial uncertainty regarding what fraction of the corporate tax burden falls on labor, but there is no robust evidence that corporate tax burdens have large depressing effects on wages. These results stand in contrast to findings of other papers; I discuss several possible reasons for this divergence.
\end{abstract}

Acknowledgements: I am grateful for financial support from the Smith Richardson Foundation. I thank Luis Lopez for his work as a research assistant. I received valuable comments from Joel Slemrod, Ed Kleinbard, and Jesse Edgerton. I am also grateful for feedback from participants at the 2011 American Tax Policy Institute conference on Competitiveness and the 2011 National Tax Association Conference in New Orleans. 


\section{Introduction}

In the present time, many OECD countries face an economic environment characterized by enormous fiscal stress, increasing economic inequality, and the pressures of global competition. In such an environment, the appropriate role of the corporate tax is an essential question. The corporate income tax raises sizable revenue, and it has important interactions with the personal income tax system. Corporate taxes fall on both domestic and multinational actors that can respond to taxation along a multitude of behavioral margins that frequently stretch across national borders. And indeed, the corporate tax has implications for the progressivity of the tax system, but these implications are anything but straightforward. Indeed, generations of corporate tax incidence models have failed to reach a clear consensus on this question, and empirical work in this area is sparse and suffers from essential limitations.

This paper investigates the nature of corporate tax incidence, considering the essential question of whether corporate taxation has a clear empirical impact on labor market outcomes. The analysis directly considers the theoretical insights of corporate tax incidence; these insights imply that the corporate tax should affect labor market outcomes by affecting the distribution of capital investments across countries, and thus capital/labor ratios, the marginal product of labor, and wages. The analysis focuses on comparably affluent OECD countries over the previous three decades; these countries are selected because of their economic relevance and the importance of finding the best data available. The analysis uses comprehensive data on labor market outcomes and corporate taxation, analyzing several sources of wage data and several ways of measuring corporate tax rates. 
Several empirical strategies are employed, in all cases undertaking a comprehensive battery of robustness and sensitivity checks. While there is some evidence in some specifications that corporate taxes depress wages, the preponderance of evidence presents a decidedly ambiguous picture. In the majority of cases, there is simply no clear and persuasive evidence of a link between corporate taxation and wages.

This result stands in contrast to work by other authors, and there are several possible explanations for the divergent findings. First, it could simply be that aggregate data are too coarse to pick up the true causal mechanisms at work, given the myriad factors that influence labor market outcomes. Second, it is possible that capital or shareholders bear the lion's share of the corporate tax burden, and prior studies have picked up spurious relationships due to methodological or data constraints.

Can this second possibility be reconciled with the increasing economic mobility of multinational firms? Globalization increases the concern that labor may bear an important share of the corporate tax burden, yet some types of globalization may avert this exact concern. In particular, multinational firms exhibit an increasing ability to delink the reporting of income from true economic activities. This delinking may imply that labor need not bear the burden of the corporate tax, since the most mobile firms have become adept at separating their taxable income from their real investment and employment choices. This consideration is discussed in the concluding sections of the paper. 


\section{Background}

\section{Theory}

Since Harberger (1962), most analyses of the corporate tax have understood that the tax affects not just the corporate sector, but indeed the entire economy. In the classic Harberger model, the corporate tax acts as a tax on capital in the corporate sector. This discourages the use of capital in the corporate sector, shrinking the corporate sector, and reducing the return to capital for the entire economy as the relatively capital intensive sector shrinks. ${ }^{1}$ The initial Harberger analysis assumed a fixed stock of labor and capital for the country as a whole; while labor and capital were mobile between the corporate and non-corporate sectors, there was a closed economy with respect to the rest of the world.

Harberger $(1995,2008)$ extended this analysis to the open economy, concluding that the feature of capital mobility was enough to undo his prior conclusions, since the (risk-free) return to capital would be equalized across countries, as would the prices of traded goods. Thus, corporate capital migrates from high-tax to low-tax locations, reducing capital/labor ratios in high-tax countries and consequently lowering the marginal product of labor and wages. In tandem, low-tax countries experience higher capital/labor ratios, a higher marginal product of labor, and higher wages.

Randolph (2006) builds on Harberger's open economy model. Again, capital is perfectly mobile across countries. While capital owners worldwide can not escape the tax, as the world capital stock is assumed fixed, domestic owners shift much of the burden of the tax to others. Using a numerical example, Randolph calculates that in the

\footnotetext{
${ }^{1}$ This assumes the corporate sector is the more capital-intensive sector, which may not necessarily be the case.
} 
U.S. case, labor would bear $70 \%$ of the burden of the tax and capital would bear $30 \%$ of the burden; workers abroad receive higher wages of a magnitude equal to $70 \%$ of the total burden, while foreign capital bears $70 \%$ of the burden.

(J.G.) Gravelle and Smetters (2006) also consider the role of the imperfect substitutability between domestic and foreign goods. If trade substitution elasticities are 1, which Gravelle and Smetters deem reasonable given estimates in the literature, then domestic labor's burden would be about $20 \%$ of the total burden.

(J.C.) Gravelle (2010) undertakes a thorough review of general equilibrium models, explaining the key assumptions that drive their findings. The paper notes that the share of the burden that falls on labor depends on several essential economic parameters: the degree of international capital mobility, international product substitution elasticities, the capital intensity of the corporate sector, the size of the country, and the degree of factor substitution. Gravelle then examines the literature that is relevant to the key elasticity assumptions. While some elasticities are hard to glean from the literature due to wide variance in estimates, she considers how the central values from the literature would affect the key estimates of general equilibrium models, finding that the results (taken together) imply that about $60 \%$ of the burden of the corporate tax falls on capital.

These studies neglect seven potentially important factors: whether the tax has residence-based elements, whether the tax subsidizes debt-financed investments, the relevance of dynamic considerations, the extent to which the corporate tax is actually a tax on economic profits, the extent to which country corporate tax changes occur in isolation, whether there is an overall effect of corporate taxation on the world capital stock, and the effect of corporate taxation on wage bargaining. First, as (J.G.) Gravelle 
and Hungerford (2010) note, since the current corporate tax has residence elements, that would cause it to fall more heavily on capital than the above models imply. Second, they also note that if the corporate tax in fact subsidizes debt-financed investments (which it may easily do, e.g., in the presence of accelerated depreciation), then raising the corporate tax could actually cause capital inflows of debt-financed investments.

Third, Auerbach (2006) notes that changes in corporate taxation have two distinct effects: effects on existing asset holders and effects on new investments. In the short run, an increase in the corporate tax will cause asset prices to fall and owners of old corporate capital assets are hurt. Over time, the rate of return on investments changes, affecting the pattern of investment and wages. This consideration implies that modeling the lag structure of corporate tax policy change effects is important. Fourth, as Auerbach (2006) notes, if the corporate tax is actually a tax on rents, then it would not impose distortions on capital investment and would be borne by shareholders. Indeed, Auerbach notes that, in $2001,0.04$ percent (i.e., less than one twentieth of $1 \%$ ) of corporations remit $62 \%$ of the corporate tax in the United States; this concentration of payments may suggest that the tax has characteristics of a tax on rents. The firms that pay corporate tax are very large, possibly suggesting a role for economies of scale and considerations of imperfect competition that may generate rents. Recent figures are even more concentrated; see IRS (2011). Auerbach also notes the importance of risk, which lowers the burden of corporate taxation.

Fifth, the extent to which country corporate tax policy changes occur in isolation is an important factor. If countries follow one another in corporate tax policy, they act more like a closed economy together. For example, if all countries raise or lower their 
corporate tax rate by the same amount, it will have different effects than if one country undertook the same policy change in isolation. Operating in tandem, the relative tax burdens across countries would stay the same, reducing the impetus for capital reallocation across countries and subsequent burdens on labor. Similar considerations lead (J.C.) Gravelle (2010) to suggest viewing the corporate tax in a manner analogous to the new view of the property tax as in Mieszkowski (1972). Under this view, the corporate tax would act like a combination of two taxes: (1) a worldwide average tax on capital that would be borne by capital and (2) profit taxes or subsidies that would be generated by country-specific deviations from the average capital tax. The latter tax would be allocated to labor and capital in a matter commensurate with the incidence assumptions of typical open-economy general equilibrium models.

Sixth, even the open economy models tend to assume that the world capital stock is fixed. To the extent that the corporate tax reduces worldwide savings and investment, it can have important long run effects on worldwide economic growth and capital formation. While Gravelle and Hungerford (2010) argue that the types of dynamic infinite-horizon models that generate large savings responses are unrealistic, to the extent that worldwide savings are diminished by corporate taxation, this would be an essential consideration.

Finally, Riedel (2011) has a model of taxing multinational firms under wage bargaining. There is a three stage bargaining process: governments choose tax rates, then multinational firms bargain with unions, and then multinational firms set their labor demands and transfer prices. In this model, an increase in corporate taxes has two main effects on labor. First, it reduces the size of the pie to be bargained over, which directly 
lowers wages. Second, it increases the value of the payroll expense deduction, thus making the firm less sensitive to wage costs, which increases wages. Under reasonable parameters, Riedel finds that the second effect dominates, such that wages increase with corporate taxes. Although this model is based on a very simplified production process, extensions of the model incorporate more nuanced considerations, and generate ambiguous effects of corporate taxation on wages.

In sum, the theoretical work in this area is rich and deep, but it raises as many questions as it answers. In the classic general equilibrium models of Harberger (1962, 1995, 2008), Gravelle and Smetters (2006), and Randolph (2006), labor bears a share of the corporate tax that depends critically on a number of parameters such as the degree of international capital mobility, the degree of international product substitution, the relative capital intensity of the corporate sector, the size of the country, and the degree of factor substitution. In Gravelle (2010), she reports that plausible benchmarks from the literature imply a shared burden between capital and labor, with capital bearing about $60 \%$ of the total burden. Yet beyond the uncertainties of these parameters, the general equilibrium theoretical models do not account for at least seven important considerations that are of vital importance in determining the true incidence of the corporate tax.

\section{Empirical Work}

Given the theoretical ambiguities, a resolution of this question must rely ultimately on empirical evidence. Yet despite the importance of the question, and the depth of the theoretical work in this area, the empirical work is thin. Some of the work is promising and provides a good starting point. Still, many of the contributions cited in policy debates have drawbacks. One pervasive problem in this work is a failure to 
consider the underlying theoretical mechanisms of open-economy general equilibrium tax incidence; empirical strategies often do not address these mechanisms. In addition, the work frequently suffers from data or methodological issues, generating findings that are not robust to relatively minor changes.

There have been several major studies that have relied on a cross-country analysis of corporate tax incidence: Hassett and Mathur (2010), Felix (2007), Desai, Foley, and Hines (2007), Arulampalam, Devereux, and Maffini (2010), and aus dem Moore and Kasten (2009). ${ }^{2}$ Hassett and Mathur (2010) is a useful starting point for this body of work. The authors use a large sample of 65 countries over the period 1981 to 2005 . They employ a fixed effects model explaining a five year average value of the natural log of wages with corporate tax rates as an independent variable as well as several control variables. Oddly, one of their controls is the value-added of workers, and they still find corporate tax effects. This itself suggests a different theoretical channel from that of the general equilibrium models above, where corporate taxes affect wages precisely because they affect capital/labor ratios and thus the resulting marginal productivity of labor. Indeed, in labor markets, wages should be determined by the value of the marginal product of labor, and thus be tightly linked to the value-added of workers. Controlling for value-added, one would not necessarily expect any effect of corporate taxes on wages.

The paper has received some criticism, most notably from Gravelle and Hungerford (2010), who first replicate their findings, but then report that the findings are very sensitive to specification choices, such as the use of a five-year average, the (lack

\footnotetext{
${ }^{2}$ In the 1960s, there was a lively debate about the empirical findings regarding corporate tax incidence, based on analyses using time series data from earlier years in the United States. Krzyzaniak and Musgrave (1963) suggested that the corporate tax might be largely shifted away from the owners of capital; Cragg, Harberger and Mieszkowski (1967) question the robustness of their finding under modest model modifications. Krzyzaniak and Musgrave (1970) respond.
} 
of) inflation adjustment, and the (lack of) PPP conversions for exchange rate differences. Further, the magnitudes of wage effects that are found by Hassett and Mathur are deemed implausible, since they imply that a dollar increase in corporate tax revenue would reduce wages by at least $\$ 22$.

Felix (2007) has a working paper that takes a similar approach, but she employs household survey data across 30 countries over the period 1979 to 2002, aggregating across households to relate corporate taxes to wages. She uses a random effects specification. Many of the regressions report statistically insignificant tax effects; the main statistically significant tax effects come in specifications that include openness interaction terms. In these cases, the main tax effect on wages is negative (as expected), but in more open countries, the tax effect is positive. While this appears contradictory to theoretical expectations (since open countries should enable more shifting of the tax onto labor), the author explains the result with the claim that openness enables corporations to more effectively avoid taxation, thus reducing the adverse wage effects of the corporate tax. In general, the conclusions of the paper seem incommensurate with the inconsistent results within the text. Also, Gravelle and Hungerford (2008) note some oddities of the specification and data set construction, since one quarter of the sample is drawn from Italy and Mexico, and no fixed effects specifications are employed.

Desai, Foley, and Hines (2007) estimate wage and interest rate sensitivity to corporate tax rates for a four year sample of U.S. multinational firm affiliates in OECD countries in the years 1989,1994, 1999, and 2004. They investigate the relative burden of the corporate tax, so they constrain the total burden shares to 1 . They find that labor bears between 45 and $75 \%$ of the total burden. However, there are some measurement issues. 
For example, it is unclear that interest rate payments of affiliates of US multinational firms should depend on corporate tax rates in a world of perfect capital mobility. More fundamentally, this sample may be insufficient for measuring long run changes in the return to capital or wages resulting from corporate taxation. The theoretical models reviewed above specify economy-wide changes in wages and returns to capital, and it is not clear that a sample of wage and interest payments by affiliates of US headquartered multinational firms will be representative of these economic forces. As one example, the corporate tax rate is likely to affect the mix of debt and equity chosen by affiliate firms, itself affecting the interest rate variables in their specifications.

Gravelle and Hungerford (2008) note several problems with this work, including the fact that, absent the restriction that labor and capital shares sum to one, there are no statistically significant results from their study. They note that many of the findings are sensitive to specification choices and are no longer statistically significant with relatively minor changes, as reported in comments on the paper by William Randolph.

Arulampalam, Devereux, and Maffini (2010) employ a rather novel approach to the question of corporate tax incidence. They consider firm level data on over 55,000 European companies in nine countries over the period 1996-2003. Cross-company variations in tax liabilities are related to value added per employee, and they find a large degree of wage sensitivity to corporate tax payments, implying that an increase in tax of $\$ 1$ would reduce wages by 49 cents. One interesting feature of this study is that it considers an alternative channel for corporate tax incidence. In Harberger-type general equilibrium models, wages and returns to capital adjust to corporate taxation in a way that is not firm-specific, since labor and capital are mobile across firms. Thus, 
Arulampalam, Devereux and Maffini are focusing on a distinct theoretical channel, the sharing of rents between workers and share-holders across firms. This rent sharing likely results from an explicit or implicit bargaining process, bringing to mind theoretical channels such as those suggested by Riedel (2011) above. Indeed, they directly control for firm labor productivity, hoping to focus the analysis solely on short run incidence effects, what they refer to as direct incidence.

One possible concern with this approach is that it is important to control for firm specific attributes (such as agility and good management) that may simultaneously enable successful firms to pay fewer taxes and higher wages without there necessarily being a causal relation between the two consequences. To address this issue the authors employ Generalized Method of Moments (GMM) to a first-differenced equation that does not contain firm-specific effects, noting possible difficulties associated with finding appropriate instruments for the application of GMM. The choice of econometric specification appears to have a large effect on the magnitudes of the results. Also, as noted by Gravelle and Hungerford (2008), there are other aspects of the econometric approach, such as the lag structure, that raise questions about the robustness of their findings.

Aus dem Moore and Kasten (2009) also have a paper that uses firm level European data. Their econometric approach employs a differences in differences approach to compare German, French and UK firms before and after the German Business Tax Reform. While their paper concludes that wages rise as corporate taxes fall, their empirical findings are ambiguous, with no statistically significant difference 
between French and German firms examined in their study, though a comparison of U.K. and German firms supports their conclusion.

Liu and Altshuler (2011) focus on rent-sharing. They use industry level variation in effective tax rates for U.S. industries over the year 1982, 1992, and 1997 to examine how tax treatment and industry concentration affect wages. Variation in tax treatment is primarily due to the asset composition in different industries, which generates different tax treatment due to depreciation allowances. There is also some variation due to interest rates, inflation rates, and the presence or absence of the investment tax credit, which was no longer in place after the Tax Reform Act of 1986. Since the authors control for time effects, the primary source of tax variation is due to the asset composition of industry investments. Also, the authors utilize industry concentration/effective tax rate interaction terms to capture the possibility that corporate tax incidence depends in part on industry concentration. They find some support for this hypothesis; the least concentrated industries exhibit no wage effects from corporate tax terms, but the effect for more concentrated industries is negative. The mean effect implies that labor may be bearing a sizable (40 to $80 \%$ ) share of the corporate tax burden.

The authors note that their analysis does not allow for a dynamic consideration of corporate tax incidence. All the wage effects are demonstrated in the same periods of the tax rate measurements. This raises some questions of interpretation. Since the domestic labor market is integrated across industries in the long run, it is likely that the long run incidence effects of corporate taxation may be substantially affected by the mobility of workers from low-wage industries to high-wage industries. An additional concern is that industry level heterogeneity might be driving some of the results. For example, if workers 
working with tax advantaged equipment are also more productive, there could be higher wages for this cause, rather than workers appropriating the benefits of lower corporate taxation.

Finally, there have been three recent papers that have considered the question of corporate tax incidence using (U.S.) state level data: Felix and Hines (2009), Carroll (2009), and Felix (2009). Felix and Hines use individual level data for the year 2000 across 50 U.S. states, noting that high-tax states have lower union premiums than low-tax states. Overall, findings indicate that workers capture just over half of the benefits of lower tax rates; this finding only holds for states without right to work laws.

Unfortunately, the authors are unable to adequately handle the presence of state-specific effects, since they utilize only one year of data. This suggests that state-specific factors such as industrial composition may have important influences on their results. For example, they compare a group of high-tax states to low-tax states for 2000, but the only low-tax state with a corporate tax in the range they describe is Michigan, which is likely to have idiosyncratic union premiums due the disproportionate influence of the auto industry in this state. Further, this paper is about rent-sharing rather than standard corporate tax incidence. Indeed, the authors control for capital/labor ratios in their specifications.

Felix (2007) also uses individual level data to relate wages to tax rates, individual characteristics, and state characteristics. The analysis does not control for state specific effects, nor any details of the tax system aside from the tax rate. Since states allocate national income to state jurisdictions by formula, details about the formula, at minimum, 
should be included in the specification. The author also excludes information about the federal rate and its interaction with the state rate.

Carroll (2007) takes a similar approach, using state level data from 1970 to 2007 to relate average hourly earnings to corporate taxes, worker productivity, and other factors. This paper has several improvements relative to Felix, including the use of time and state fixed effects as well as consideration of the federal layer of taxation. However, there are some peculiar aspects of the specifications, including using corporate collections divided by state personal income as one measure of the tax rate. This measure is likely influenced by other considerations aside form tax treatment, since states vary in terms of how much gross state product is in the corporate sector. Further, results using conventional marginal tax rates are not statistically significant at the normal $95 \%$ confidence benchmark. Also, the tax effects are not robust to modest specification changes, as the author notes. Further, like many of the other studies above, the author controls for worker productivity, yet still finds (at times) that corporate taxation influences wages. Since the main theoretical channel through which taxes affect wages is via their effect on productivity, it leads one to again wonder whether the tax effects in evidence are in fact indicative of possible omitted variables that drive a spurious correlation between corporate tax rates and wages.

A review of the previous empirical work in this area thus indicates several crucial problems with the analyses. Most fundamental, the prior work does not directly address the economic mechanisms suggested by theory. Instead, studies often consider the effect of corporate taxes on wages, controlling for value added or capital/labor ratios, and thus controlling for the very mechanism they are purporting to study. In addition, tax effects 
on capital/labor ratios are likely to take substantial time to occur, suggesting the importance of allowing for lags in adjustment to tax policy; often, empirical analyses focus instead on contemporaneous relationships.

Or, studies employ firm-level or industry-level data, abstracting from this set of theoretical mechanisms entirely and instead focusing on a division of rents. However, to the extent that the corporate tax is really a tax on rents rather than on capital in the corporate sector, the efficiency implications of the tax are different. A tax on pure profits may affect where pure profits are reported, and perhaps the underlying economic activity, but it will have a lesser effect on relative factor use. Indeed, for a tax on pure profits, the decisions about capital and labor input use that would maximize before-tax profits would also maximize after-tax profits; this is not the case for a tax on capital or a tax on corporate capital. As a final point, it should be noted that results in these corporate tax incidence papers find a much higher degree of rent sharing with labor than is common in the larger literature. ${ }^{3}$

Finally, many of the above papers have serious econometric or data issues. Yet one has empathy for the researchers in this area. The theory does not provide a crystalline roadmap for investigation, exogenous changes in tax policy are difficult to identify, and the true consequences of variations in corporate tax policies likely occur over time, with substantial lags from the policy changes. In environments where many important economics forces change simultaneously, this can stymie careful empirical investigation.

\footnotetext{
${ }^{3}$ While the labor economics literature tends to find that rent sharing exists, their estimates of the fraction of rents that accrue to labor tend to be quite a bit smaller. See Budd, Konings, and Slaughter (2005), Van Reenen (1996), and citations to this literature within these papers.
} 


\section{Data}

The subsequent analysis considers the incidence of corporate taxation by focusing on data from OECD countries over the previous thirty years, beginning in 1981. One of the issues that has thwarted empirical investigators in this area has been the difficulty of assembling comparable data on labor market outcomes across countries. Labor market surveys collect a wide variety of information, differing in terms of parameters such as the time interval of measurement (weekly wages, annual wages, hourly wages), the comprehensiveness of compensation measures (pre or post tax, with or without benefits), and the scope of those surveyed (men and women, employees and self-employed, wage earners or salaried workers).

When using international data, one must put local currency measures into some comparable format, either by examining changes in local wages directly (adjusting for local inflation), or by converting into dollars. In the latter case, to make the data truly comparable, it is important to adjust for variations in the purchasing power of the local currency. Since exchange rates fluctuate far more widely than the underlying macroeconomic fundamentals, researchers may run the risk of conflating wage changes and exchange rate changes if local currency values are simply converted to a common currency using market exchange rates. ${ }^{4}$

Since this analysis focuses on OECD countries, some of the data constraints are less troublesome than they would be with a larger selection of countries, but locating strictly comparable data on wages remains difficult. In the following analysis, I have considered several possible sources of wage data.

\footnotetext{
${ }^{4}$ As just one example, a failure to consider purchasing power parity adjustments would lead one to conclude that dollar wages in Japan increased by $100 \%$ between 1985 and 1989 in the OWW data set, with almost half of that change between 1985 and 1986. Similar problems abound.
} 
First, the OECD provides data on average annual wages, both in constant dollars and in constant dollars adjusted for purchasing power parity (PPP) differences. Data are fairly comprehensive in coverage although they are only available for the later two-thirds of the time period under consideration, since $1990 .{ }^{5}$ Second, there are labor market data from the International Labor Organization (ILO). Remco Oostendorp and Richard Freeman have used the ILO data to create the Occupational Wages around the World (OWW) database. These data are available for only a subset of the years (1983 to 2003), and the data coverage is incomplete. However the authors undertake a laborious set of tasks, detailed in Oostendorp (2005), to make the data comparable. ${ }^{6}$

Third, the ILO provides a variety of survey data through their Labor Statistics database for most of the time period under consideration, including 1981 to 2008. I took several steps to make these data comparable. ${ }^{7}$ Finally, the Bureau of Labor Statistics

\footnotetext{
${ }^{5}$ The OECD also provides a mean hourly wage index for OECD countries that is somewhat more comprehensive in both country and time period coverage than the aforementioned series. However, these data are indexed so that $2005=100$, so they are only useful in terms of considering trends in wage changes rather than comparisons of levels of wages.

${ }^{6}$ The standardized wage that they report is the average monthly wage for workers in the whole country. Various correction factors are used for variables that are not in the standard format. Data are organized by occupation, which is not ideal for the purpose here. However, the authors provide a table of averages across occupations; this table can be easily replicated from the disaggregated data that they provide. Still, it should be noted that occupational data vary both across countries and over time due in part to the fact that wages are being reported for different occupations. Also, I further adjust the data in two respects: data are adjusted for PPP conversions to avoid an undue influence of exchange rate fluctuations, and data are adjusted for dollar inflation to create a constant dollar series.

${ }^{7}$ I restricted consideration to the most similar series, reported for aggregates of men and women. I gave preference to survey series that reported later years, that included all employees, and that reported monthly data. However, when data were reported in other time intervals, I converted the data. For example, I used OECD data on average annual hours worked to convert hourly data to monthly data by multiplying hourly wages by annual hours worked, and then dividing by 12 ; likewise, weekly data were converted to monthly data. Converting data to constant dollars took several steps. Local currencies were converted to dollars using PPP exchange rates. Care was taken for the many countries, particularly the Euro countries, that changed currency during the time period. Then, the resulting dollar wages were adjusted for inflation to generate real dollar wage series.
} 
provides international comparisons of hourly compensation costs in manufacturing. The most comprehensive series is for production workers; this series is available from 1981 to 2009 for over 30 countries including most of the OECD. ${ }^{8}$ Compensation costs include pay received by workers, benefits, and employer remitted social-insurance expenditures and labor-related taxes. Since the supply-side of the labor market is generally believed to bear the entirety of labor related taxes and regulations, this measure is likely to capture the true pre-tax productivity of workers as reflected by their labor costs. (The mix of labor taxes and direct pay will differ by country due to the importance of labor taxes, but the marginal product of labor should equal the combined values of employer compensation costs.) I adjusted these data to account for the difference between PPP and market exchange rate fluctuations and to put series in constant dollar terms.

In the following analyses, I refer to these wage data sources as OECD, OWW, ILO, and BLS data. I use all four sources of wage level data in comparable real PPPadjusted dollar terms. ${ }^{9}$ The main wage variables, in the form that they are used in the analysis, have correlations of between 0.76 and 0.89 . The data vary quite a bit in terms of country and year coverage, as shown in Table 1 . In most of the analyses, I restrict consideration to those series where at least half of the possible year/country pairs are available; thus, the OWW data are only used for the first approach below. ${ }^{10}$

I make use of several corporate tax measures. This is another essential variable that is difficult to measure in a consistent way across countries. For example, the statutory corporate tax rate does not reflect many other important features of the

\footnotetext{
${ }^{8}$ Data are included in both level and indexed form.

${ }^{9} \mathrm{I}$ also use the BLS indexed wage data in real local currency terms.

${ }^{10}$ In a September 2011 draft of this paper, I used the OWW data in more analyses, without any change in the underlying conclusions. Here these analyses are eliminated to conserve space.
} 
corporate tax system that affect true corporate tax burdens. For this reason, I utilize four different measures of the corporate tax rate: the top central government statutory rate (from the OECD, adjusted for surtaxes), the combined central and sub-central statutory tax rate (from the OECD, adjusted for central government deductibility of sub-central taxation), the effective tax rate (from the U.S. Bureau of Economic Analysis), and the ratio of corporate tax revenues to GDP (from the OECD). ${ }^{11}$

Each of these measures has flaws, and no measure is necessarily superior to the others. Statutory rates neglect many provisions that determine the true tax treatment of firms. Sub-central tax rates should be included ideally, but a simple average of such rates may neglect substantial variation among sub-central rates as well as the possibility that firms are more likely invest in low-tax sub-central jurisdictions. Effective tax rates here are based only on a subset of firms, the affiliates of U.S. based multinational corporations. ${ }^{12}$ Their tax payments may not be representative of those by the universe of firms operating in a particular jurisdiction. Finally, corporate revenue to GDP ratios are

\footnotetext{
${ }^{11}$ The effective tax rate is based on survey data from operations of U.S. multinational firms. It is calculated as the foreign taxes paid by foreign affiliates of U.S.-based multinational firms in a given country relative to their net income (adding back foreign taxes in the denominator). Thus, if U.S. affiliates pay $\$ 500$ million in foreign taxes based on $\$ 1.5$ billion in net income, the effective tax rate would be calculated as $\$ 500 /(\$ 1,500+500)=25 \%$.

${ }^{12}$ I also experimented with using average effective tax rates from Devereux et al (2002) that have since been updated to 2005 and are available at http://www.ifs.org.uk/publications/3210 (last accessed December 5, 2011). These effective tax rates are calculated based on a hypothetical investment project and details of country tax laws including depreciation allowances and tax system structure. One advantage of these data is that they are not based on a subset of firms; however, the creation of the data entails numerous assumptions about the particulars of the investment project that may not be accurate or representative. Further, utilizing this data source curtails the number of observations dramatically relative to the BEA data, from 760 observations to 495 observations. Nonetheless, I checked all of the following analyses with this substitute data series. While some of the results were substantively different, the overall spirit of the resulting conclusions did not change. Further, some of the observed differences were due to the country composition of the smaller sample rather than the measure of the effective tax rate.
} 
likely influenced by both the share of the corporate sector in the economy and overall corporate profitability; this may be a rather noisy indicator of tax treatment.

While no particular tax rate variable is ideal, together they provide a good picture of the tax treatment of corporations in a particular country. Irrespective of the choice of tax variable, there is a large amount of policy variation in the data, hopefully enabling an insightful inquiry. For example, over $55 \%$ of observations indicate a statutory tax rate change over the previous five years.

Other variables are more straightforward and come from conventional data sources with somewhat less need for adjustment. They are discussed in the data appendix.

\section{Analysis}

The following analysis has several objectives. First, it will use the most comprehensive data available on both labor market outcomes and taxation. In each case, results will be generated from several wage data sources and several tax rate variables. Second, it will examine the question of corporate tax incidence from the perspective of open-economy general equilibrium tax incidence theory, considering the main economic mechanisms suggested by that theory. The analysis will thus abstract from rent-sharing channels that may operate at the firm or industry level, focusing instead on economywide corporate tax incidence. Third, it will focus on OECD countries as a particularly relevant set of "peer" countries that share both similar levels of economic development and more comprehensive data.

I have taken several approaches to analyzing the data. First, I take Hassett and Mathur (2010) as a model specification, using more comprehensive data. Hassett and 
Mathur (2010) is the only prior paper to utilize cross-country data at an aggregate level. ${ }^{13}$ For reasons discussed above, these data are most suited to establishing the nature of general equilibrium tax incidence. Second, I consider a systematic regression analysis that proceeds in stages, according to the theoretical mechanisms described in openeconomy general equilibrium tax incidence theory. While some of the empirical specification choices are necessarily ad hoc, I also investigate departures from the main choices. Finally, I turn to a vector autoregression [VAR] analysis of the relationships between the key variables analyzed in this inquiry. A VAR analysis has the advantage of not making assumptions regarding the exogeneity of variables, and it can reveal empirical relationships without imposing excessive structure on the investigation.

\section{Approach 1: The Hassett and Mathur Specification}

As a starting point, I employ the baseline specification of Hassett and Mathur (2010). In this specification, the dependent variable is the five year average of the wage rate over the sub-periods 1981-85, 1986-90, 1991-95, 1996-2000, and 2001-5. They hypothesize that this average wage variable will depend on the corporate tax rate (negatively), manufacturing value-added per worker, the inflation rate, the personal income tax rate, and trade to GDP ratios. The independent variables are measured at the beginning of each five-year time period. All specifications include country fixed effects and period dummies.

I began by considering this same specification, with a few important changes.

First, my sample is limited to OECD countries. When Hassett and Mathur consider non-

\footnotetext{
${ }^{13}$ Felix (2007) uses household survey data on wages, Desai, Foley, and Hines (2007) use data on U.S. multinational firm affiliates, and other papers rely on industry, firm, or state-level data.
} 
OECD countries separately they find similar tax effects. ${ }^{14}$ Second, I use a variety of wage data sources, all of which are adjusted into real dollars on a PPP basis. This is an important change, since otherwise exchange rate fluctuations will generate large dollar wage movements that do not reflect underlying labor market fundamentals. ${ }^{15}$ The four data sources used are the BLS data on hourly wages of production workers, the ILO survey data on monthly wages of employees, the Occupational Wages around the World [OWW] data on monthly average wages, and OECD data on average annual wages. Third, I use four measures of the tax variable: the top statutory rate at the central government level, the top combined rate, the effective tax rate, and corporate tax revenues as a share of GDP. Fourth, my data series typically extend over a longer period of time. ${ }^{16}$ Otherwise, the specification is similar to that of Hassett and Mathur, and it includes the same control variables as their baseline specification (manufacturing valueadded per worker, the inflation rate, the personal income tax rate, and the trade to GDP ratio).

Table 2 summarizes the results. To conserve space, I simply report the tax coefficients, but other results were generally as expected. ${ }^{17}$ As is immediately apparent from this table, there is no clear empirical relationship between corporate tax rate variables and wage variables across the sixteen ways of considering the data. There are three statistically significant negative coefficients. For example, results using the

\footnotetext{
${ }^{14}$ This result is from a 2006 preliminary draft of their paper.

${ }^{15}$ In the current (2010) version of the paper, Hassett and Mathur include local consumer price indexes to capture price level differences across countries. However, since exchange rate movements are highly volatile, they likely swamp local price index changes. Thus, converting data into dollars using market exchange rates will still introduce large unexplained wage changes due to the volatility of exchange rates.

${ }^{16}$ Wage data from the BLS and the OECD extend to 2009. Wage data from the ILO extend to 2008, and wage data from the OWW dataset extend to 2003.

${ }^{17}$ Full results are available upon request.
} 
combined statutory tax rate for the BLS hourly wage data indicate that a corporate tax rate one percentage point higher is associated with an hourly wage one quarter of one percent lower. ${ }^{18}$ However, thirteen of the sixteen regressions indicate no statistically significant negative relationship between corporate tax variables and wages.

These specifications were also considered with the value-added explanatory variable omitted. As discussed in Section II, the main channel through which corporate taxation should affect wages is by altering capital allocation across countries, thus affecting the value added, marginal product, and wages of workers. Therefore, I also considered all sixteen specifications with the value-added variable omitted. It is expected that tax effects would be larger (more negative), since any negative effect of corporate taxes on value-added would also be captured in the tax rate coefficient. Yet in all sixteen cases, the results on the tax variables are statistically equivalent to those reported above. ${ }^{19}$ While one would expect larger tax effects with the value-added variable omitted, the results are surprisingly similar.

I also considered specifications that included relative tax variables instead of level tax terms. These relative tax variables were calculated as the country tax rate minus the average OECD country tax rate in that year. Given the downward trend over this time period in statutory corporate tax rates, using relative tax terms will account for the fact that a $30 \%$ tax rate may seem much lower in comparison to other countries in the

\footnotetext{
${ }^{18}$ Hassett and Mathur typically find tax coefficients that are two to three times larger than this coefficient implies.

${ }^{19}$ There were two small changes. In the case of the combined tax rate for OECD annual data, the tax variable is almost (with $94 \%$ confidence) statistically negative, with a point estimate of 0.208 . And, in the case of the central tax rate for the OWW data, the tax coefficient is no longer statistically negative with $95 \%$ confidence.
} 
beginning of the sample period (1981) than it would at the end (2009). Results, both with and without the value-added terms, were nearly identical to those above.

Finally, I experimented with the inclusion of a host of other explanatory variables, including political variables showing the orientation of the executive and legislative branches of government, the average years of schooling of the population over 25, and other economic control variables. ${ }^{20}$ In no cases were the tax results strengthened in statistical significance or magnitude, although the inclusion of political variables eliminated the statistical significance of one tax coefficient.

\section{Approach 2: Investigating the General Equilibrium Tax Incidence Mechanism}

The following approach separates the incidence question into two parts.

(1) Is there a relation between corporate tax rate variables and capital investment?

(2) Is there a relationship between labor market outcomes and capital investment?

If the economic mechanisms driving the open-economy general equilibrium models of corporate tax incidence are at work, both questions should be answered affirmatively. Higher corporate taxes should be associated with lower levels of investment, and the lower capital/labor ratio should correspond with adverse labor market outcomes. For lowtax countries, the opposite outcomes are expected, with higher investment levels and better labor market outcomes.

As a starting point, consider a simple illustration of the relationship between tax variables and the subsequent wage growth. Since it will take time for a given tax policy change to affect investment and wages, I consider an average of the six most recent years

\footnotetext{
${ }^{20}$ Political data are from the DPI2010, the Database of Political Institutions from the World Bank.
} 
of tax data (the current year and the five previous years). ${ }^{21}$ For these tax rate variables, I consider their relative values in comparison to the mean value of OECD countries for that particular year. Thus, if a country had an average relative tax rate of -0.05 , that would imply that over the six most recent years of data, the tax rate averaged a value that was five percentage points lower than that of other countries in the same years. Again, I use several measures of the tax rate: the statutory combined rate of central and sub-central layers of government, the effective tax rate calculated from U.S. Bureau of Economic Analysis data, and the corporate revenue to GDP ratio.

Figure 1 relates these values to subsequent wage growth, using BLS data on indexes of hourly production worker wages, adjusted for local inflation. ${ }^{22}$ The growth rate of wages is averaged for four quartiles of the sample, sorted by relative tax rate. Thus, the "bottom" quartile has relative tax rates that are low relative to other countries in the six most recent years, and the "top" quartile has relative tax rates that are high relative to other countries in the six most recent years.

Considering statutory tax measures, there is some evidence that lower tax countries experience higher real wage growth; the bottom quartile by relative tax rate has $1.3 \%$ hourly wage growth each year, the second quartile has $1.4 \%$ growth, and the top two quartiles have just $1.0 \%$ wage growth. Still, although these differences in average wage growth are in the expected direction, the means themselves are not statistically different from one another. The bottom quartile has an average relative tax rate at least

\footnotetext{
${ }^{21}$ Even simpler illustrations show no relationship between corporate tax rate variables and wages. Scatter plots between all wage measures and all tax measures (16 in total) show no obvious indications of a relationship between corporate taxation and wages. I also considered a graphical analyses of the more than twenty cases where the corporate tax rate changed by more than 7 percentage points; there was no discernible visual pattern of clear breaks in the trend of wage growth in the years following the tax rate change.

${ }^{22}$ This is the most complete wage data series.
} 
4.5 percentage points lower than the average country, while the top quartile has an average relative tax rate that is at least 4.0 percentage points higher than the average country. ${ }^{23}$

Results for the other two tax measures are more ambiguous. For effective tax rates, the bottom quartile of tax rate countries (with at least a 7.6 percentage point lower tax rate than other countries over the previous years) experience the same wage growth, $1.2 \%$ on average, as the top quartile of tax rate countries (with at least a 7.6 percentage point higher tax rate over the previous years). The same is true with the revenue measure. Looking further, a natural next step is to examine the relationship between these same relative tax rate variables and investment variables. If high tax rates are responsible for lower wage rates, the main theoretical channel that drives this result is the relationship between relative tax rates and investment. If a country has a higher relative tax rate, they should experience a loss of capital investment relative to countries with lower tax rates, and thus a lower marginal product of labor and lower wages. ${ }^{24}$

Figure 2 examines the average annual changes in the ratio of gross fixed capital formation to GDP, again by quartile of relative tax rates. In most periods, this variable is negative, since gross capital formation relative to GDP is decreasing more often than increasing over this time period. Thus one expects that the change in gross fixed capital formation will be less negative for lower tax countries, but perhaps still negative. Yet, for

\footnotetext{
${ }^{23}$ Figures in Appendix B show these relationships broken down over time period, distinguishing years prior to 1993, years between 1993 and 2000, and years after 2000. The negative relationship between statutory tax rates and wage growth is not apparent in the early years of the sample (before 1993), becomes negative in the middle time period (1993-2000), and is particularly pronounced in the final period, 2001-2009. The other tax rates show unclear patterns.

${ }^{24}$ This abstracts from the possibility that corporate taxes merely take away super-normal profits that would have been shared between owners and workers, thus having a lesser effect on capital stocks.
} 
all three tax variables, there is no evidence that lower tax countries experience greater growth (or lesser declines) in gross fixed capital formation relative to GDP. Figure 2 casts doubt on a simplistic interpretation of the evidence regarding statutory tax rates in Figure 1. If clear, theoretically founded relationships exist between corporate tax treatment and subsequent wage outcomes, a more sophisticated economic analysis is required to detect and clarify the nature of that relationship.

Indeed, simple illustrations may not illuminate the true effect of corporate tax influences since other important influences are also acting on wages and investment, and these influences may confound the interpretation of raw correlations. For example, macroeconomic factors likely have a large influence on investment. In addition, different countries may have different base levels of investment relative to GDP due to the nature of their economies, their stage of development, and long term institutional, cultural, or other country-specific factors. There may also be time specific influences that are associated with economic shocks, trends, or other events.

The specifications reported in Table 3 model how all of these influences affect investment. The dependent variable is the ratio of gross fixed capital formation to GDP. The regressions consider the impact of corporate tax variables, again considering the average of the most recent six years (the current year and the five previous) of relative tax rates in comparison to the average of OECD countries. The specifications control for the growth of real GDP from the prior year and the unemployment rate, both proxies for the state of the macroeconomy. In addition, there are both country-specific fixed effects and time-specific effects, to consider the influence of the factors described above. 
Columns (1), (2), (3), and (4) differ only by considering the influence of the four tax rates examined in the analyses above: the combined statutory rate, the central government statutory rate, the effective tax rate, and the corporate revenue/GDP ratio. In all regressions, both time and country-specific effects are highly jointly statistically significant. As expected, the growth rate typically has a statistically significant positive coefficient, whereas the unemployment rate has a highly statistically significant negative coefficient.

Surprisingly, the only statistically significant tax coefficients are positive, for both the average relative statutory tax rate, and the average relative corporate tax revenue ratios. This is a puzzling finding. I considered several alternative specifications. For example, I consider the specification in changes, considering how changes in the gross fixed capital formation to GDP ratio were related to changes in the growth rate, changes in the unemployment rate, and a five-year change in the relative tax rate. In most cases, the tax coefficients were again zero; the one exception was again a positive coefficient. Also, I consider tax variables in levels rather than in relative terms; this too did not change the above conclusions.

Since the corporate tax incidence mechanism is driven by a relationship between corporate taxation and the capital stocks that workers have at their disposal, it is also useful to examine the relationship between corporate tax variables and capital/labor ratios. Table 4 examines specifications that consider how capital/labor ratios depend on corporate tax variables, controlling for the real PPP-adjusted GDP per-capita of countries (in order to account for the fact that capital/labor ratios tend to be higher in higher income countries), country fixed effects, and time fixed effects. Again, columns (1), (2), (3), and 
(4) differ only by considering the influence of the four tax rates examined in the analyses above. In the case of the central government statutory rate, there is a statistically significant negative relationship between tax rates and the $\mathrm{K} / \mathrm{L}$ ratio; however for the other tax rate variables, the coefficients are statistically indistinguishable from zero. Thus, there is only very limited evidence in favor of the open-economy general equilibrium corporate tax incidence mechanism.

The second stage of the analysis considers the relationship between investment and labor market outcomes. Economic theory has long established a relationship between these two variables, based on the premise that countries with a higher capital stock benefit from higher worker productivity and thus higher wages. Indeed there is a large body of empirical data that verifies that workers in more capital abundant countries earn higher wages. ${ }^{25}$ Table 5 shows a simple series of regressions explaining wages, using the three wage series with the most data availability: BLS data on hourly production worker wages, ILO data on monthly wages, and OECD data on average annual wages. Wages are related to the average years of schooling for the population aged 25 years and above, recent capital stock to labor force ratios (the average of the current and previous five years), the growth rate of the labor force over the previous five years, the growth rate of the economy over the previous five years, and the current unemployment rate. The specifications include country and year effects; these are always highly jointly

\footnotetext{
${ }^{25}$ While economic growth theory makes the clear prediction that more capital abundant countries should have higher labor productivity and higher wages, international trade theory predicts factor price equalization (and thus equal wages) between all countries. Factor price equalization holds with diversified production, common technology, and free trade in goods. Still, trade economists have long noted that this prediction is spectacularly refuted by the data. When one allows for factor augmenting technical differences between countries, the theory performs somewhat better.
} 
statistically significant. While this is an ad hoc specification, other choices were also considered.

In most cases, results conform to expectations; it is expected that a lower unemployment rate, lower labor force growth, higher economic growth, higher capital/labor ratios, and higher levels of schooling will increase wages. Most of the statistically significant coefficient signs are as expected, although there is an anomalous finding for the relation between unemployment and annual wages in column (3). All of the capital/labor terms have a positive sign and are statistically significant with greater than $99 \%$ confidence.

In theory, there is no clear rationale for including corporate tax terms in specifications such as those shown in Table 5 . If corporate taxes affect wages by affecting investment and the subsequent capital stocks that workers utilize, then the effect of corporate taxation on wages is indirect, and it should be captured by capital investment terms. An effect on the wage rate above and beyond the effect on investment could capture other mechanisms, such as rent sharing between owners and workers, but these are not the mechanisms at work in general equilibrium tax incidence models. Of course, such effects could also be due to omitted variables or spurious correlations.

Nonetheless, I also consider these wage specifications with the four tax terms included: the average of recent years' values of (i) the relative statutory combined tax rate, (ii) the relative statutory central tax rate, (iii) the relative effective tax rate, and (iv) the relative corporate revenue to GDP ratio. Given the three sources of wage data and the four tax terms, this generates 12 equations. ${ }^{26}$ In three cases the tax coefficient is statistically negative, in six cases the tax coefficient is statistically positive, and in three

\footnotetext{
${ }^{26}$ Due to space constraints, results are not reported here, but they are available upon request.
} 
cases the tax coefficient is statistically indistinguishable from zero. If these same specifications are considered with the tax terms, but omitting the capital/labor terms so that the tax terms also capture indirect effects of investment reductions, the tax coefficient results are statistically equivalent.

Some of the results above appear to support the hypothesis that higher corporate tax rates lower wages. But the complete body of evidence casts doubt, and the evidence in support of the main channel of causality in open-economy general equilibrium corporate tax incidence models is not persuasive. Still, one might question how to reconcile this evidence with a quite sizable body of evidence that indicates that foreign direct investment is quite responsive to corporate tax differences across countries. One possibility, discussed in more detail in Section V, is that clientele effects may be important. For example, Desai and Dharmapala (2009) find some evidence of substitution between foreign portfolio investment and foreign direct investment in response to tax incentives. Also, as noted above, corporate taxation may actually subsidize debt-financed investments. It is thus plausible that some types of investment or some types of investment finance are discouraged by high levels of corporate taxation, but that other types of investment and investment finance at least partially take their place. Such a substitution could offset much of the aggregate impact of corporate taxation on the capital/labor ratio and thus on wages.

\section{Approach 3: Vector Autoregressions}

In many respects, the above analyses are unsatisfying. It is difficult to know the ideal specifications to employ, results are sensitive to choices regarding which data on wages and tax rates are used, and the specifications are rife with endogeneity concerns. 
Indeed, wages and investment could easily influence some of the right hand side variables, and one can imagine third factors that would affect both dependent and independent variables. In this section, I consider an alternative way of approaching these questions, a vector autoregression model.

In a vector autoregression (VAR) model, a system of equations are estimated, where each variable is specified to depend on its own lagged values and lagged values of the remaining variables. In such models, the distinction between exogenous and endogenous variables becomes moot, as the method simply considers how a group of variables evolves based on their own previous values. Only lagged values of variables are included on the right hand side.

There are some essential advantages to these methods. Given that the true underlying causal relationships are at times ambiguous, results from these equations may help determine whether causal relationships exist. In particular, if past values of one variable $(\mathrm{x})$ are found to be a statistically significant influence on a different variable (y) even in the presence of the past values of such a variable (y), that is often taken as evidence that there may be a causal relationship between the two variables. ${ }^{27}$ Noncausality is similarly implied if the past values of $\mathrm{x}$, considered jointly, are not a statistically significant influence on $y$ in the presence of past values of $y$.

I consider a system of equations that includes the following:

Wage $_{i t}=\sum_{i} \alpha_{i}+\sum_{n=1}^{5}$ Wage $_{i, t-n}+\sum_{n=1}^{5} \operatorname{Tax}_{i, t-n}+\sum_{n=1}^{5} K /$ L Ratio $_{i, t-n}+\sum_{n=1}^{5} G D P_{i, t-n}+\sum_{n=1}^{5}$ Unem $_{i, t-n}+\sum_{i=1}^{x} \alpha_{i}$

\footnotetext{
${ }^{27}$ Still, there remains the possibility that a third omitted influence could be an important causal factor driving both $\mathrm{x}$ and $\mathrm{y}$.
} 
$K /$ Latio $_{i t}=\sum_{i} \alpha_{i}+\sum_{n=1}^{5} K /$ Latio $_{i, t-n}+\sum_{n=1}^{5}$ Tax $_{i, t-n}+\sum_{n=1}^{5}$ Wage $_{i, t-n}+\sum_{n=1}^{5} G D P_{i, t-n}+\sum_{n=1}^{5}$ Unem $_{i, t-n}+\sum_{i=1}^{x} \alpha_{i}$

$\operatorname{Tax}_{i t}=\sum_{i} \alpha_{i}+\sum_{n=1}^{5} \operatorname{Tax}_{i, t-n}+\sum_{n=1}^{5}$ Wage $_{i, t-n}+\sum_{n=1}^{5} K /$ L Ratio $_{i, t-n}+\sum_{n=1}^{5} \operatorname{GDP}_{i, t-n}+\sum_{n=1}^{5}$ Unem $_{i, t-n}+\sum_{i=1}^{x} \alpha_{i}$

In this model, the included variables are measures of wages, corporate tax rates, capitallabor ratios, real GDP, and unemployment rates; all specifications include country fixed effects. ${ }^{28}$ Investigating this system of regressions, one is not presuming that any particular endogenous variable is determined by a set of exogenous variables. Instead, one is considering whether past values of variables on the right hand side influence current values of the variables on the left-hand side, controlling for the past values of the lefthand side variables.

Yet it should be noted that a VAR approach is not without disadvantages. VAR systems of equations are often not robust to changes in the number of lags, the frequency of the data, or the inclusion of additional variables. Therefore, I consider many robustness checks below. $^{29}$

Since the individual regressors are typically highly collinear, individual $t$ statistics are unreliable, so the influence of variables on the right-hand side is considered by performing $\mathrm{F}$ tests of the joint statistical significance of the group of regressors. Thus, to ascertain the possible influence of corporate taxes on wages, one would examine whether past values of corporate tax values as a group had a statistically significant impact on wage levels, controlling for past wage levels and the other variables in the model.

\footnotetext{
${ }^{28}$ I discuss alternative specifications below. They are not reported here but available upon request.

${ }^{29}$ VARs are also frequently criticized as being atheoretical, although it is possible to derive VARs formally as reduced forms of dynamic structural models.
} 
Twelve VAR models are run, to consider the three different sources of wage data and the four different possible corporate tax variables. ${ }^{30}$ Table 6 reports the $\mathrm{F}$ statistics for the tax variables for each of the 12 wage equations. If the tax variables as a group have a statistically significant effect on wage variables, the six year impulse response effect of tax rates on wages is indicated below the F statistic. In eight cases, there is no statistically significant relationship between lagged values of the corporate tax variables as a group and wages, controlling for prior wages. In four cases the tax variables were jointly statistically significant. In these cases, I considered impulse response functions to consider the effect of tax variables on wage outcomes. In two cases, the overall effect of taxes on wages was ambiguous and very small, as the lagged tax variables had both positive and negative effects that nearly offset each other, resulting in an approximately zero net effect. In the third case the overall effect of taxes on wages was positive and in the fourth case, the corporate tax variables had a negative relationship with wages. Thus, at first glance, the VAR analysis does not support a clear causal relationship between corporate tax variables and wages.

Table 7 shows results for the same VAR analysis, but using relative tax rates instead of level tax rates. Again, these relative tax variables were calculated as the country tax variable minus the OECD average for the same tax variable. Results were little changed; in all but three cases the tax variables were jointly statistically insignificant. Of the three statistically significant groups of tax effects, in two cases the impulse response functions show that the six-year effect of taxes on wages was negative.

\footnotetext{
${ }^{30}$ Since the OWW wage data have fewer observations, I do not report results for the OWW wage data in this version of the paper. Still, in each of these VARs, the F tests indicate that the tax variables are jointly statistically insignificant in OWW wage equations.
} 
Given the known sensitivity of VAR analysis to the number of lags and variables included, I also experimented with other specifications. For example, I considered a model with ten lags for both level and relative tax rates. Table 8 shows the results for the relative tax term specifications; the level tax rate results were nearly identical. Of the twelve VAR systems considered, in eight cases there was no evidence of a jointly statistically significant relationship between lagged values of the corporate tax variables and wages. In the other cases, the impulse response functions indicate that there is one case of a positive relationship, one case of a negative relationship, and two cases of an ambiguous overall effect of corporate tax rates on wages.

As a further test of robustness, I tried the inclusion or substitution of different variables. In specifications not reported here, I utilized gross fixed capital formation to GDP ratios instead of capital-labor ratios. I also ran specifications including average years of schooling (of the population over 25) and political variables in the analysis. In all cases, the pattern of results was quite similar to those reported here. I also ran the VAR models above without the investment terms in the wage regressions. Results were nearly identical.

\section{Discussion}

Section II discussed a substantial body of theoretical work that suggests that labor should bear some of burden of the corporate tax. In open-economy general equilibrium models, the movement of capital in response to corporate tax rate differentials reduces wages in high-tax countries, increasing wages in low-tax countries. The evidence 
reviewed in this paper casts doubt on the empirical robustness of this claim. While some evidence is supportive of this mechanism, the preponderance of evidence is not. ${ }^{31}$

Yet prior studies have often found such a link. ${ }^{32}$ Why are there differences in results? First, some of the prior studies that have relied on cross-country data have been less complete in their analyses. They have relied on less complete data than utilized here, and data are not always adjusted for purchasing power and other sources of incompatibility. At times, results are not robust to changes in specification choices; omitted variables or spurious correlations may be present. Since natural policy experiments are rare and credible identification strategies are difficult, sensitivity analyses are particularly important.

Second, some studies use industry or firm level data to identify rent-sharing mechanisms. While these studies are intriguing, they do not address economy-wide incidence and are thus less informative for policy-makers contemplating a change in corporate tax policy. For example, if the rent-sharing mechanism is key, then cuts to the corporate tax will allow more rents to fall into the hands of shareholders and workers, who will share the excess. However, since labor markets are integrated across firms and industries, workers will eventually move from job to job and industry to industry, eroding wage differences. Thus, the economy-wide wage effects from such rent-sharing may be smaller than the rent-sharing specifications alone would lead one to believe. ${ }^{33}$

\footnotetext{
${ }^{31}$ Further, there is no discernible pattern in the supporting evidence. Particular tax rate data and/or wage data are not consistently associated with results that are more favorable to the openeconomy general equilibrium tax incidence mechanism.

32 One exception is a study by Feldmann (2011), but this study focuses on employment rather than wages. Feldmann finds that corporate tax rates are negatively associated with unemployment.

${ }^{33}$ Also, it is notable that the labor economics literature rarely finds rent sharing to the degree found in these papers on corporate tax incidence. See citations above (footnote 3 ).
} 
Third, despite the theoretical reasons to believe that labor will bear some of the corporate income tax, there are several competing considerations. Models of general equilibrium incidence neglect several factors that might reduce the extent to which labor bears the corporate tax: the extent to which the corporate tax has residence elements, the fact that debt-financed investments are typically subsidized through the corporate tax, the extent to which corporate tax changes do not occur in isolation, and elements related to risk and the nature of competition.

Fourth, it is possible that clientele effects may undo some of the wage effects associated with corporate taxation. For example, if there are investors based in worldwide tax system countries, they will view high tax rates as less of a deterrent than those based in exemption countries. Also, Desai and Dharmapala (2009) find evidence of substitution between foreign portfolio investment and foreign direct investment in response to tax incentives. In addition, corporate taxation may actually subsidize debt-financed investments. In general, the type of investment (portfolio versus direct, debt versus equity financed, etc.) may be far more sensitive to corporate tax treatment than the overall level of investment that determines the resulting capital stock. If corporations are mere intermediaries in global capital markets in which a wide assortment of investors with different tax treatments invest, tax policy changes could affect the ownership and financing patterns of assets more than they affect the aggregate level of investment in different countries. ${ }^{34}$

\footnotetext{
${ }^{34}$ Djankov et al (2010) note a large literature, to which they contribute, that suggests a relationship between corporate taxation and investment. As they note, other studies do not typically use cross-country analysis. In their analysis, they employ a cross-section of 85 countries in 2004; no time series variation is utilized. They find statistically significant relationships between both statutory and effective tax rates and foreign direct investment; effective tax rates, but not statutory rates, have a statistically significant effect on overall investment. Some of the
} 
Finally, an additional important consideration may be driving these results. In recent decades, the economy has become more global, leading to a rethinking of corporate tax incidence. Yet, accompanying this globalization, there has been an increased divergence between the location of economic activity (such as investment, employment, and sales) and the location of income for tax purposes. I have discussed these trends at great length in prior work, including Clausing $(2009,2011)$, Avi-Yonah and Clausing (2008), and Avi-Yonah, Clausing, and Durst (2009). ${ }^{35}$ This divergence could reduce the wage effects of relative corporate tax rates, since agile firms can move income without commensurate movements of investment and jobs. Indeed, many of the most global companies have become increasingly adept at the creation of stateless income, as discussed in Kleinbard (2011). ${ }^{36}$ If firms can respond to tax differences among countries through financial or organizational decisions, this will lower the tax sensitivity of real activity, thus reducing possible adverse effects on labor associated from taxinduced reductions in the capital stock.

tax effects lose their statistical significance as a complete set of control variables are added, although the findings are robust to the inclusion of some control variables.

${ }^{35}$ Many examples of this divergence are available. In 2008, foreign affiliates U.S. multinational firms book far more profit in low-tax countries than their activities in these countries would suggest. For example, six of the top seven profit countries have effective tax rates of $4 \%$ or lower: Netherlands, Luxembourg, Ireland, Bermuda, Switzerland, and Singapore. The combined population of these six countries, 34 million, is less than that of California, yet they account for $46 \%$ of all foreign profits. None of these six countries are a top-ten employment country for U.S. multinational firms in 2008.

${ }^{36}$ A preliminary examination of the tax payments of the largest U.S. corporations supports the idea that some firms are far more global than others, and the global firms are more adept at lowering their effective U.S. tax burden well below the statutory rate. Helman (2009) and Citizens for Tax Justice (2011) consider data from financial statements, demonstrating that effective tax rates vary widely. Large domestic firms, like Walmart and CVS, often have high effective tax rates. Globally integrated firms, like GE, Hewlett-Packard, IBM, and Procter and Gamble, have far lower effective tax rates. 


\section{Conclusion}

This paper has described a thorough search for the nature of corporate tax incidence. Prior literature on this question includes a rich set of theoretical contributions where the relative burden of corporate taxation depends on a host of economic parameters including the openness of the economy, the size of the economy, capital/labor substitution elasticities, cross-country product substitution elasticities, and sectoral factor intensities. The theoretical literature neglects a number of features that likely affect the incidence of the corporate tax, including the extent to which the tax falls on economic profits, residence elements of the tax, and net subsidization of debt financed investments. Previous empirical work has often found that corporate taxation acts to reduce wages. Results range from about $40 \%$ to over $100 \%$ of the total burden falling on labor. Yet many of these papers do not address the central economic mechanisms behind openeconomy general equilibrium tax incidence, and results are not always robust.

This paper has sought to improve understanding of corporate tax incidence by making a few contributions. First, I have examined the robustness of empirical results by using an unusually comprehensive collection of data on labor market outcomes, focusing on OECD countries in the period since 1981. I have utilized multiple international wage series and have carefully transformed the data to make them as compatible as possible; I have also considered multiple measures of the corporate tax burden. Second, I have employed several approaches to analyzing the data: estimating the specifications suggested by the most relevant previous study on corporate tax incidence, building a more comprehensive set of regression models, and finally undertaking a vector 
autoregression analysis. Third, in all cases, I focus on the economic mechanisms implied by open-economy general equilibrium tax incidence models.

At the end of the searching, I find some evidence that suggests that corporate taxation may lower wages, but the preponderance of evidence does not suggest any wage effects from corporate taxation. Despite the findings of other studies, perhaps this is not a surprising result. Corporate tax incidence is difficult to model, and many models leave out important considerations. Economies are very complex, and myriad economic forces determine labor market outcomes. Perhaps we should be more surprised if the data $d o$ give a clear answer to this complex question.

Still, despite limitations, other studies have frequently found that corporate taxes lower wages. What can account for these results? It is possible that data and methodological issues are at work, but it may also reflect other factors. For example, it may be that corporate taxation does depress wages, but the complexity of real world economies makes it difficult to observe these relationships with such a comprehensive approach.

It is also possible that capital continues to bear the corporate tax. For instance, while corporate taxation may discourage some types of investment, it may not have a large enough effect on overall investment to cause a substantial reduction in wages. Or, the tax burden may fall predominately on economic profits, and thus reduce the rents of both shareholders and others who share their rents. In this context, it is important to note that the reporting of profit in particular tax jurisdictions is becoming increasingly discretionary. Truly global multinational firms are adept at using complex chains of ownership together with tax-motivated decisions regarding the holding of intangible 
property, the structure of finance, and the transfer pricing of intermediate goods, in order to report income where it is most lightly taxed. If global firms separate the location of their profits from the location of their investments and employment, then workers need not bear the burden of the corporate tax. The firms that are adept at shifting income face a lighter tax burden, which need not adversely affect their workers. Whereas immobile firms behave like closed-economy actors, and thus they are unlikely to generate the openeconomy incidence result.

I will close with a political economy point, mentioned by Lawrence Summers at a Hamilton Project forum in $2007 .{ }^{37}$ He noted that it was indeed possible that corporate stockholders and managers who resist the corporate tax are not really acting in their own interests because they don't understand corporate tax incidence, since corporate taxes will ultimately be borne by their workers. ${ }^{38}$ But it seems far more plausible that they have calculated their interests correctly.

\footnotetext{
${ }^{37}$ A transcript of commentary is available on the Hamilton Project web site. See www.hamiltonproject.org/events/reforming taxation in the global age/ (Last accessed 11 October 2011.)

${ }^{38}$ A counterargument is that firm owners and managers may be legitimately concerned for their workers. Yet that consideration would also lead these actors to oppose the payroll tax, both parts of which fall on labor.
} 


\section{References}

Altshuler, R., B. Harris, and E. Toder, 2010, Capital Income Taxation and Progressivity in a Global Economy, Tax Policy Center Working Paper.

Arulampalam, W., M. P. Devereux, and G. Maffini, 2010, The Direct Incidence of Corporate Taxes on Wages, IZA DP No. 5293.

Auerbach, A., 2006, Who Bears the Corporate Tax? A Review of What We Know, Tax Policy and the Economy 20, 1-40.

Aus dem Moore, N., and T. Kasten, 2009, Do Wages Rise When Corporate Tax Rates Fall? Differences-in-Differences Analyses of the German Business Tax Reform 2000 (RhineWestphalia Institute for Economic Research).

Avi-Yonah, R. S., and K. A. Clausing, 2008, Reforming Corporate Taxation in a Global Economy: A Proposal To Adopt Formulary Apportionment, in J. Furman and J. E. Bordoff eds, Path to Prosperity: Hamilton Project Ideas on Income Security, Education, and Taxes (Brookings Institution Press, Washington) 319-344.

Avi-Yonah, R. S., K. A. Clausing, and M. C. Durst, 2009, Allocating Business Profits for Tax Purposes: A Proposal to Adopt a Formulary Profit Split, Florida Tax Review 9, 497-553.

Budd, J. W., J. Konings, and M. J. Slaughter, 2005, Wages and International Rent Sharing in Multinational Firms, Review of Economics and Statistics 87, 73-84.

Carroll, R., 2009, Corporate Taxes and Wages: Evidence from the 50 States, Tax Foundation Working Paper No. 8.

Citizens for Tax Justice, 2011, Corporate Taxpayers and Corporate Dodgers: 2008-2010. .

Clausing, K. A., 2009, Multinational Tax Avoidance and Tax Policy, National Tax Journal 57, 703-725.

— , 2011, The Revenue Effects of Multinational Firm Income Shifting, Tax Notes, 15801586.

Cragg, J. G., A. C. Harberger, and P. Mieszkowski, 1967, Empirical Evidence on the Incidence of the Corporation Income Tax, Journal of Political Economy 75, 811-821.

Desai, M., and D. Dharmapala, 2009, Taxes, institutions and foreign diversification opportunities, Journal of Public Economics 93, 703-714.

Desai, M. A., C. F. Foley, and J. R. Hines Jr., 2007, Labor and Capital Shares of the Corporate Tax Burden: International Evidence, Working Paper.

Devereux, M. P., et al, 2002, Corporate Income Tax Reforms and International Tax Competition, Economic Policy, 451-495.

Djankov, S., et al, 2010, The Effect of Corporate Taxes on Investment and Entrepreneurship, American Economic Journal: Macroeconomics 2, 31-64.

Feldmann, H., 2011, The Unemployment Puzzle of Corporation Taxation, Public Finance Review, forthcoming.

Felix, R. A., 2007, Passing the Burden: Corporate Tax Incidence in Open Economies, Federal Reserve Bank of Kansas City Working Paper.

_ 2009, Do State Corporate Taxes Reduce Wages?, Federal Reserve Bank of Kansas City Economic Review.

Felix, R. A., and J. James R. Hines, 2009, Corporate Taxes and Union Wages in the United States, National Bureau of Economic Research Working Paper No. 15263.

Gentry, W. M., 2007, A Review of the Evidence on the Incidence of the Corporate Income Tax, OTA Papers (Department of the Treasury, Washington). 
Gravelle, J. C., 2010, Corporate Tax Incidence: Review of General Equilibrium Estimates and Analysis Congressional Budget Office Working Paper Series (Washington DC).

Gravelle, J. G., and T. L. Hungerford, 2008, Corporate Tax Reform: Should We Really Believe the Research?, Tax Notes.

- 2010, Corporate Tax Reform: Issues for Congress, CRS Report for Congress.

Gravelle, J. G., and K. A. Smetters, 2006, Does the Open Economy Assumption Really Mean

That Labor Bears the Burden of a Capital Income Tax?, Advances in Economic Analysis and Policy 6, Article 3.

Gyourko, J., and J. Tracy, 1989, The Importance of Local Fiscal Conditions in Analyzing Local Labor Markets, Journal of Political Economy 97, 1208-1231.

Harberger, A. C., 1962, The Incidence of the Corporate Income Tax, Journal of Political Economy 70, 215-240.

— 1995 , The ABC's of Corporate Tax Incidence: Insights into the Open Economy Case, Tax Policy and Economic Growth (American Council for Capital Formation, Washington) 51-73.

- 2008, Corporation Tax Incidence: Reflections on What Is Known, Unknown, and Unknowable, in D. a. Zodrow ed, Fundamental Tax Reform (MIT Press, Cambridge) 283-307.

Hassett, K. A., and A. Mathur, 2010, Spatial Tax Competition and Domestic Wages (American Enterprise Institute).

Helman, C., 2010, What the Top U.S. Companies Pay in Taxes, Forbes. April 1.

Jensen, M. H., and A. Mathur, 2011, Corporate Tax Burden on Labor: Theory and Empirical Evidence, Tax Notes, 1083-1089.

Internal Revenue Service Statistics of Income, 2011, Corporate Income Tax Returns, 2008 (Washington DC).

Kleinbard, E., 2011, Stateless Income's Challenge to Tax Policy, Tax Notes, 1021-1042.

Krzyzaniak, M., and R. A. Musgrave, 1963, The Shifting of the Corporation Income Tax (Johns Hopkins Press, Baltimore).

— 1970, Corporation Tax Shifting: A Response, Journal of Political Economy 78, 768773.

Liu, L., and R. Altshuler, 2011, Measuring the Burden of the Corporate Tax Under Imperfect Competition, Working Paper.

Mieszkowski, P., 1972, The Property Tax: An Excise Tax or a Profits Tax?, Journal of Public Economics 1, 73-96.

Randolph, W. C., 2006, International Burdens of the Coporate Income Tax, Congressional Budget Office Working Paper Series (Washington DC).

Riedel, N., 2010, The Downside of Formula Apportionment: Evidence of Factor Demand Distortions, International Tax and Public Finance 17, 236-258.

— 2011, Taxing Multi-Nationals Under Union Wage Bargaining, International Tax and Public Finance.

Van Reenen, J., 1996, The Creation and Capture of Rents: Wages and Innovation in a Panel of U.S. Companies, Quarterly Journal of Economics 111, 195-226. 
Figure 1: Growth for BLS Hourly Production Worker Wage Index

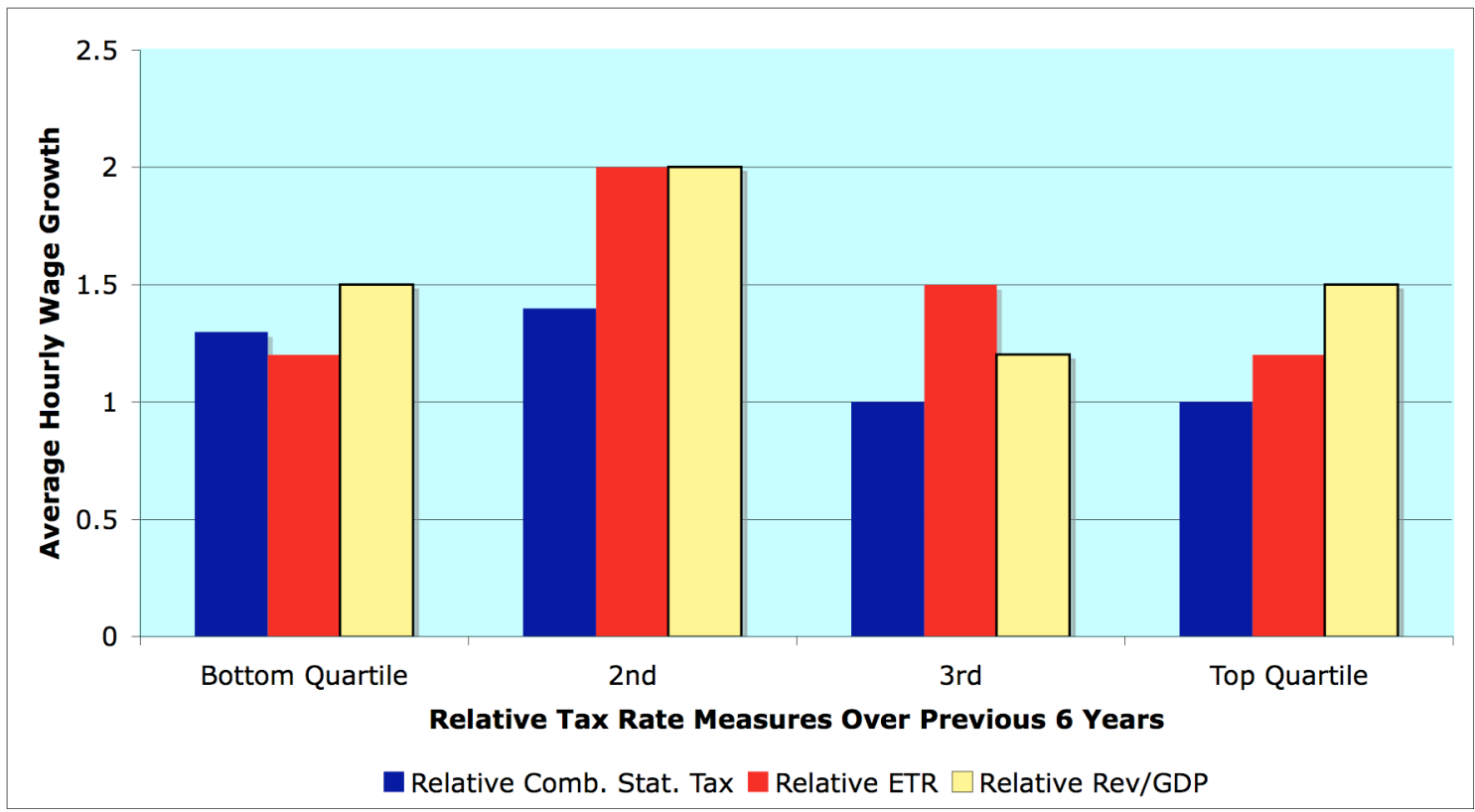

Figure 2: Change in Gross Fixed Capital Formation/GDP

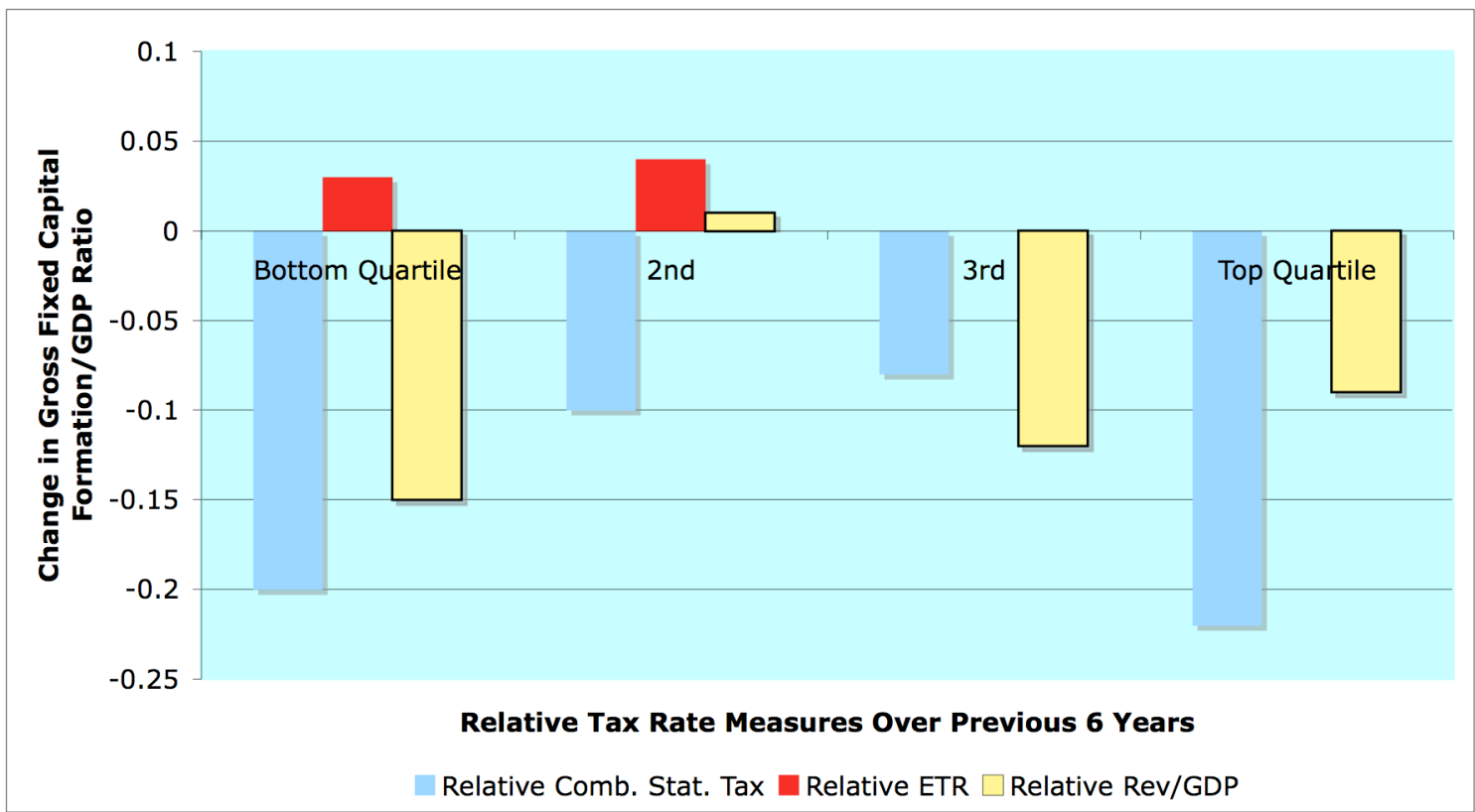

Note that the average value of the change in the gross fixed capital formation variable is zero for the top two quartiles of effective tax rate countries. Hence, their bars do not appear in the figure. 
Table 1: Wage Data Coverage

\begin{tabular}{llll}
\hline & Years & Countries & No. Obs. \\
\hline BLS & $1981-2009$ & 27 & 728 \\
ILO & $1981-2008$ & 32 & 518 \\
OWW & $1983-2003$ & 27 & 349 \\
OECD & $1990-2009$ & 26 & 490 \\
\hline
\end{tabular}

Table 2: Tax Coefficients from Hassett and Mathur (Baseline) Method (with additional data sources)

\begin{tabular}{lllll}
\hline & $\begin{array}{l}\text { BLS } \\
\text { Hourly }\end{array}$ & $\begin{array}{l}\text { ILO } \\
\text { Monthly }\end{array}$ & $\begin{array}{l}\text { OECD } \\
\text { Annual }\end{array}$ & $\begin{array}{l}\text { OWW Data } \\
\text { (monthly) }\end{array}$ \\
\hline $\begin{array}{l}\text { Combined } \\
\text { tax rate }\end{array}$ & $-0.262^{*}$ & -0.083 & -0.071 & $-0.617^{*}$ \\
Central & $(0.103)$ & $(0.141)$ & $(0.101)$ & $(0.275)$ \\
Tax Rate & -0.187 & -0.089 & 0.034 & $-0.725^{*}$ \\
Corp.Revenue/GDP & $(0.113)$ & $(0.151)$ & $(.117)$ & $(0.340)$ \\
& $(0.621)$ & $(0.830)$ & $(0.487)$ & 0.921 \\
Effective Tax Rate & -0.026 & 0.083 & -0.027 & $(2.175)$ \\
& $(0.071)$ & $(0.107)$ & $(0.066)$ & 0.160 \\
& & & & $(0.160)$ \\
No. of 5-yr periods & $109-133$ & $87-107$ & $103-108$ & $57-75$ \\
No. of countries & $25-26$ & $25-30$ & $24-25$ & $22-23$ \\
\hline
\end{tabular}

Standard errors in parentheses.

${ }^{*} p<0.05,{ }^{* *} p<0.01$ 
Table 3: Regressions Explaining Gross Fixed Capital Formation/GDP

\begin{tabular}{|c|c|c|c|c|}
\hline & (1) & (2) & (3) & (4) \\
\hline $\begin{array}{l}\text { Growth of } \\
\text { Real GDP }\end{array}$ & $\begin{array}{c}0.0844^{*} \\
(0.0389)\end{array}$ & $\begin{array}{c}0.0980^{*} \\
(0.0407)\end{array}$ & $\begin{array}{c}0.0722 \\
(0.0403)\end{array}$ & $\begin{array}{c}0.0913^{*} \\
(0.0406)\end{array}$ \\
\hline Unem. Rate & $\begin{array}{l}-0.647^{* * *} \\
(0.0338)\end{array}$ & $\begin{array}{l}-0.627^{\text {*** }} \\
(0.0363)\end{array}$ & $\begin{array}{l}-0.706^{* * *} \\
(0.0356)\end{array}$ & $\begin{array}{l}-0.643^{* * *} \\
(0.0378)\end{array}$ \\
\hline $\begin{array}{l}6 \text { yr. Rel. Tax } \\
\text { (Stat Comb.) }\end{array}$ & $\begin{array}{l}0.0451^{* *} \\
(0.0166)\end{array}$ & & & \\
\hline $\begin{array}{l}6 \text { yr. Rel. Tax } \\
\text { (Stat Central) }\end{array}$ & & $\begin{array}{c}0.000751 \\
(0.0177)\end{array}$ & & \\
\hline $\begin{array}{l}6 \text { yr. Rel. Tax } \\
\text { (Eff Tax Rate) }\end{array}$ & & & $\begin{array}{l}0.00516 \\
(0.0164)\end{array}$ & \\
\hline $\begin{array}{l}6 \text { yr Rel. Tax } \\
\text { (Rev/GDP) }\end{array}$ & & & & $\begin{array}{c}0.0913^{*} \\
(0.0406)\end{array}$ \\
\hline Constant & $\begin{array}{c}0.272^{* * *} \\
(0.00463)\end{array}$ & $\begin{array}{c}0.269^{* * *} \\
(0.00494)\end{array}$ & $\begin{array}{c}0.276^{* * *} \\
(0.00447)\end{array}$ & $\begin{array}{c}0.264^{* * *} \\
(0.00487)\end{array}$ \\
\hline Fixed Effects? & yes & yes & yes & yes \\
\hline Time Effects? & yes & yes & yes & yes \\
\hline $\begin{array}{l}\mathrm{N} \\
\mathrm{R}^{2}\end{array}$ & $\begin{array}{r}546 \\
5 \quad 8\end{array}$ & 524 & 518 & 601 \\
\hline & 0.58 & 0.54 & 0.55 & 0.49 \\
\hline
\end{tabular}

Standard errors in parentheses.

${ }^{*} p<0.05,{ }^{* *} p<0.01,{ }^{* * *} p<0.001$ 
Table 4: Regressions Explaining ln (K/L)

\begin{tabular}{|c|c|c|c|c|}
\hline & (1) & (2) & (3) & (4) \\
\hline $\begin{array}{l}\text { GDP } \\
\text { per-capita }\end{array}$ & $\begin{array}{l}0.0321 \\
(.0342)\end{array}$ & $\begin{array}{l}0.110^{* *} \\
(.0351)\end{array}$ & $\begin{array}{c}-0.0295 \\
(.0389)\end{array}$ & $\begin{array}{l}0.0546 \\
(.0404)\end{array}$ \\
\hline $\begin{array}{l}6 \text { yr. Rel. Tax } \\
\text { (Stat Comb.) }\end{array}$ & $\begin{array}{l}0.00980 \\
(0.0818)\end{array}$ & & & \\
\hline $\begin{array}{l}6 \text { yr. Rel. Tax } \\
\text { (Stat Central) }\end{array}$ & & $\begin{array}{l}-0.253^{* *} \\
(0.0827)\end{array}$ & & \\
\hline $\begin{array}{l}6 \text { yr. Rel. Tax } \\
\text { (Eff Tax Rate) }\end{array}$ & & & $\begin{array}{c}0.102 \\
(0.0832)\end{array}$ & \\
\hline $\begin{array}{l}6 \text { yr Rel. Tax } \\
\text { (Rev/GDP) }\end{array}$ & & & & $\begin{array}{l}-0.553 \\
(0.537)\end{array}$ \\
\hline Constant & $\begin{array}{l}10.84^{* * *} \\
(0.333)\end{array}$ & $\begin{array}{l}10.06^{* * *} \\
(0.342)\end{array}$ & $\begin{array}{l}11.36^{* * *} \\
(0.373)\end{array}$ & $\begin{array}{l}10.61^{* * *} \\
(0.394)\end{array}$ \\
\hline $\begin{array}{l}\text { Fixed Effects? } \\
\text { Time Effects? }\end{array}$ & $\begin{array}{l}\text { yes } \\
\text { yes }\end{array}$ & $\begin{array}{l}\text { yes } \\
\text { yes }\end{array}$ & $\begin{array}{l}\text { yes } \\
\text { yes }\end{array}$ & $\begin{array}{l}\text { yes } \\
\text { yes }\end{array}$ \\
\hline $\begin{array}{l}\mathrm{N} \\
\mathrm{R}^{2}\end{array}$ & $\begin{array}{l}601 \\
0.76\end{array}$ & $\begin{array}{l}579 \\
0.79\end{array}$ & $\begin{array}{l}582 \\
0.75\end{array}$ & $\begin{array}{l}644 \\
0.75\end{array}$ \\
\hline
\end{tabular}

Standard errors in parentheses.

${ }^{*} p<0.05,{ }^{* *} p<0.01,{ }^{* * *} p<0.001$

Standard errors in parentheses.

${ }^{*} p<0.05,{ }^{* *} p<0.01,{ }^{* * *} p<0.001$ 
Table 5: Regressions Explaining In (Wages)

\begin{tabular}{|c|c|c|c|}
\hline & $\begin{array}{c}(1) \\
\text { BLS Hourly Wage }\end{array}$ & $\begin{array}{c}(2) \\
\text { ILO Monthly Wage }\end{array}$ & $\begin{array}{c}(3) \\
\text { OECD Annual } \\
\text { Wage }\end{array}$ \\
\hline $\begin{array}{l}\text { Average Years } \\
\text { Schooling }\end{array}$ & $\begin{array}{l}0.0398^{* * *} \\
(0.00609)\end{array}$ & $\begin{array}{l}0.0529^{* * *} \\
(0.00743)\end{array}$ & $\begin{array}{l}-0.00561 \\
(0.00489)\end{array}$ \\
\hline $\begin{array}{l}\text { Recent Years } \\
\text { K/L Ratio }\end{array}$ & $\begin{array}{l}0.562^{* * *} \\
(0.0394)\end{array}$ & $\begin{array}{l}0.447^{* * *} \\
(0.0410)\end{array}$ & $\begin{array}{l}0.251^{* * *} \\
(0.0343)\end{array}$ \\
\hline $\begin{array}{l}\text { Last } 5 \text { Years } \\
\text { Labor Force Growth }\end{array}$ & $\begin{array}{l}-0.504^{* * *} \\
(0.105)\end{array}$ & $\begin{array}{c}-0.578^{* * *} \\
(0.113)\end{array}$ & $\begin{array}{c}0.0523 \\
(0.0746)\end{array}$ \\
\hline $\begin{array}{l}\text { Last } 5 \text { Years } \\
\text { GDP Growth }\end{array}$ & $\begin{array}{c}0.152^{*} \\
(0.0712)\end{array}$ & $\begin{array}{c}0.0263 \\
(0.0767)\end{array}$ & $\begin{array}{l}0.276^{* * *} \\
(0.0481)\end{array}$ \\
\hline Unemployment & $\begin{array}{l}-0.117 \\
(0.185)\end{array}$ & $\begin{array}{c}-1.117^{* * *} \\
(0.199)\end{array}$ & $\begin{array}{l}0.338^{*} \\
(0.136)\end{array}$ \\
\hline $\begin{array}{l}\text { Time Effects } \\
\text { Country Effects }\end{array}$ & $\begin{array}{l}\text { Yes } \\
\text { Yes }\end{array}$ & $\begin{array}{l}\text { yes } \\
\text { yes }\end{array}$ & $\begin{array}{l}\text { yes } \\
\text { yes }\end{array}$ \\
\hline $\begin{array}{l}\mathrm{N} \\
\mathrm{R}^{2}\end{array}$ & $\begin{array}{l}542 \\
0.71\end{array}$ & $\begin{array}{l}368 \\
0.72\end{array}$ & $\begin{array}{l}435 \\
0.78\end{array}$ \\
\hline
\end{tabular}

All dependent variables are in $\ln$ terms. Standard errors in parentheses.

${ }^{*} p<0.05,{ }^{* *} p<0.01,{ }^{* * *} p<0.001$ 
Table 6:

Vector Autoregression Results: F Statistics Indicating Joint Statistical Significance of Tax Variables in Wage Equations (5 lag specification)

\begin{tabular}{llll}
\hline & $\begin{array}{l}\text { BLS } \\
\text { Hourly }\end{array}$ & $\begin{array}{l}\text { ILO } \\
\text { Monthly }\end{array}$ & $\begin{array}{l}\text { OECD } \\
\text { Annual }\end{array}$ \\
\hline $\begin{array}{l}\text { Combined } \\
\text { Tax Rate }\end{array}$ & 1.85 & 0.72 & $\begin{array}{l}3.65^{* *} \\
(-.0004)\end{array}$ \\
$\begin{array}{l}\text { Central } \\
\text { Tax Rate }\end{array}$ & 1.29 & 1.21 & $3.45^{* *}$ \\
Corp.Revenue/GDP & $\begin{array}{l}4.27^{* *} \\
(+.006)\end{array}$ & 1.12 & $(-.04)$ \\
& & & $3.2^{* *}$ \\
& 0.99 & 0.43 & $(+.02)$ \\
Effective Tax Rate & & & 1.14 \\
\hline${ }^{*} p<0.05,{ }^{* *} p<0.01$ & & &
\end{tabular}

The effect on wages in year six of the impulse response function in indicated below statistically significant $\mathrm{F}$ statistics.

Table 7:

Vector Autoregression Results: F Statistics Indicating Joint Statistical Significance of Tax Variables in Wage Equations (5 lag specification, relative tax terms)

\begin{tabular}{llll}
\hline & $\begin{array}{l}\text { BLS } \\
\text { Hourly }\end{array}$ & $\begin{array}{l}\text { ILO } \\
\text { Monthly }\end{array}$ & $\begin{array}{l}\text { OECD } \\
\text { Annual }\end{array}$ \\
\hline $\begin{array}{l}\text { Relative Combined } \\
\text { Tax Rate }\end{array}$ & 2.18 & 0.66 & $\begin{array}{l}4.09^{* *} \\
(-.012)\end{array}$ \\
$\begin{array}{l}\text { Relative Central } \\
\text { Tax Rate }\end{array}$ & 1.14 & 0.80 & $4.13^{* *}$ \\
$\begin{array}{l}\text { Relative } \\
\text { Corp.Revenue/GDP }\end{array}$ & 1.98 & 0.61 & $(-.03)$ \\
$\begin{array}{l}\text { Relative } \\
\text { Effective Tax Rate }\end{array}$ & 0.55 & & $2.39^{* *}$ \\
\end{tabular}

${ }^{*} p<0.05,{ }^{* *} p<0.01$

The effect on wages in year six of the impulse response function in indicated below statistically significant $\mathrm{F}$ statistics. 
Table 8:

Vector Autoregression Results: F Statistics Indicating Joint Statistical Significance of Tax Variables in Wage Equations (10 lag specification, relative tax terms)

\begin{tabular}{llll}
\hline & $\begin{array}{l}\text { BLS } \\
\text { Hourly }\end{array}$ & $\begin{array}{l}\text { ILO } \\
\text { Monthly }\end{array}$ & $\begin{array}{l}\text { OECD } \\
\text { Annual }\end{array}$ \\
\hline $\begin{array}{l}\text { Relative Combined } \\
\text { Tax Rate }\end{array}$ & $\begin{array}{l}2.20^{*} \\
(-.01)\end{array}$ & $\begin{array}{l}2.27^{*} \\
(0.00)\end{array}$ & 1.82 \\
$\begin{array}{l}\text { Relative Central } \\
\text { Tax Rate }\end{array}$ & 1.40 & 1.32 & $2.29^{*}$ \\
$\begin{array}{l}\text { Relative } \\
\text { Corp.Revenue/GDP }\end{array}$ & $\begin{array}{l}2.44^{* *} \\
(0.00)\end{array}$ & 1.65 & $(+.02)$ \\
$\begin{array}{l}\text { Relative } \\
\text { Effective Tax Rate }\end{array}$ & 0.58 & 1.41 & 0.84 \\
\hline$p<0.05,{ }^{* *} p<0.01$ & & & \\
\hline * & & & \\
\hline
\end{tabular}

The effect on wages in year six of the impulse response function in indicated below statistically significant $\mathrm{F}$ statistics. 


\section{Appendix A: Data Sources}

Both wage data and tax rate data are discussed extensively in Section III of the paper. Other variables are described here.

The following data are from World Bank databases.

- Gross fixed capital formation. These data were previously labeled by the World Bank as gross domestic investment. They cover land improvements, plant, equipment, and machinery, as well as the construction of buildings and infrastructure. It does not include inventories.

- Private capital flows. Private capital flows include net foreign direct investment and portfolio investment. Portfolio investment includes debt and equity transactions but excludes authorities' reserve transactions.

- Real GDP.

- Trade as a Share of GDP. This is the sum of exports and imports of goods and services as a share of GDP.

- Average years of schooling. This is the average years of education among people over age 25. Data were reported for every five years, and interpolation was used for the intermediate years.

- Industry value added per worker.

- Inflation rate.

- Labor force. People aged 15 and over who meet the ILO definition of economically active. Includes both employed and unemployed.

The following data are from the OECD.

- The unemployment rate. This is a harmonized unemployment rate giving the number of unemployed persons as a share of the civilian labor force, which includes employees, self-employed, unpaid family workers, and the unemployed.

- The personal income tax rate. This is the highest bracket rate. 


\section{Appendix B}

Figure B1: BLS Hourly Wage Index, by Relative Statutory Tax Rates

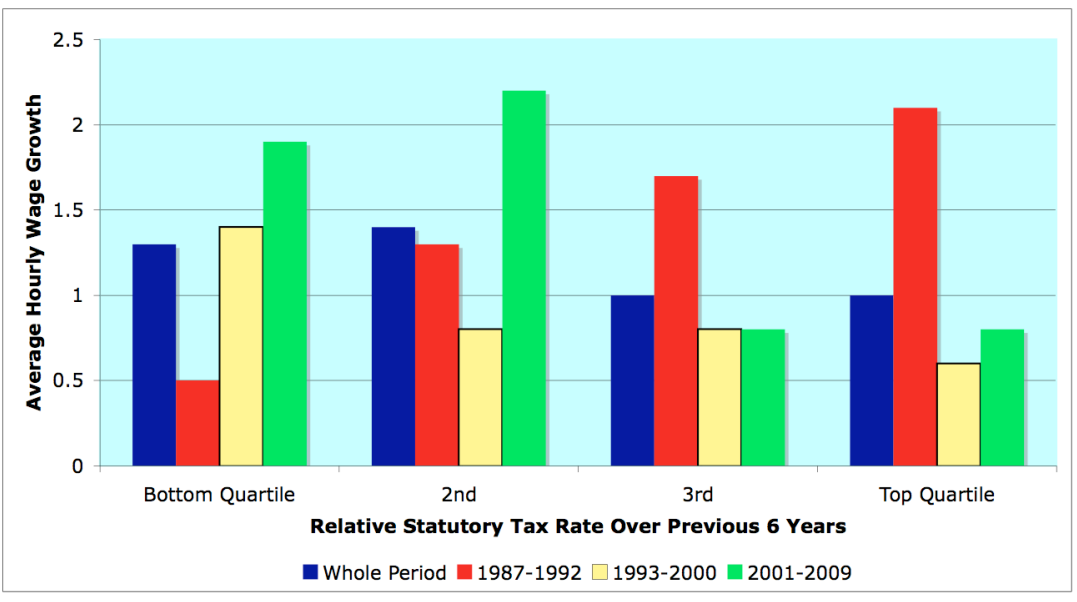

Figure B2: BLS Hourly Wage Index, by Relative Effective Tax Rates

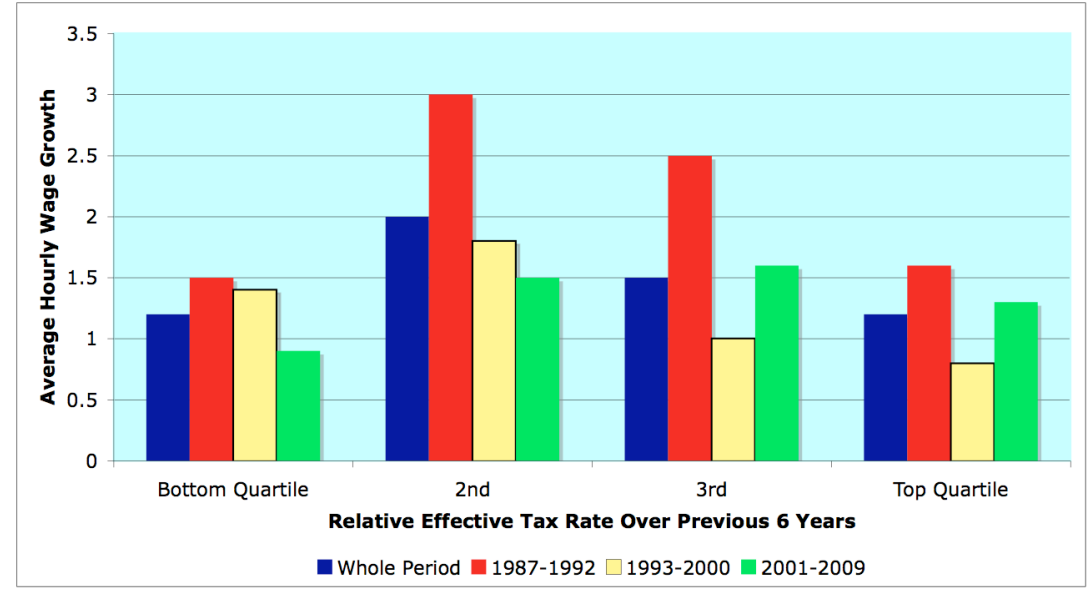

Figure B3: BLS Hourly Wage Index, by Relative Revenue/GDP Ratios



